\title{
EFFECTS OF METHOD AND LENGTH OF STORAGE ON EGG QUALITY OF GIANT AFRICAN LAND SNAIL (A. MARGINATA)\#
}

\author{
EFECTOS DEL MÉTODO Y DURACIÓN DEL ALMACENAMIENTO, SOBRE LA CALIDAD \\ DEL HUEVO DEL CARACOL GIGANTE AFRICANO (A. MARGINATA)
}

\author{
Abiona, J.A. ${ }^{1 *}$; Adio, B.R. ${ }^{1}$; Osinowo, O.A. ${ }^{1}$ and Abioja, M.O. ${ }^{1}$ \\ 'Department of Animal Physiology. College of Animal Science \& Livestock Production. University of \\ Agriculture. Abeokuta. Nigeria. abionajohn@yahoo.ca
}

\author{
AdDitionAL KEYWORDS \\ Archachatina marginata.
}

\section{SUMMARY}

Seventy five giant African land snails were used to investigate the effect of method and length of storage on snail egg quality. Snail eggs were stored either in fridge (cold), in a container on a shelf (ambient) or in earthen pot (earthen) for 1, 2 3 and 4 weeks. Parameters measured were: external (egg length, egg weight, egg circumference, egg shape index, percentage egg weight loss, percentage egg volume loss) and internal (albumen weight, albumen height and egg pH). Storage method had no effect on external egg parameters measured but affected internal parameters $(p<0.001)$. Length of storage had significant effect $(p<0.01)$ on albumen height, and weight and volume percentage losses (internal parameters). Egg weight loss was highest in earthen pot and lowest in both cold and ambient for the first two weeks of storage, thereafter, it increases with length of storage. Egg volume loss was also found to be highest in earthen pot and lowest in cold storage. It can be concluded that room and cold storage can be used for snail egg (Archachatina marginata) between 1-2 weeks of storage for better egg quality.

\section{RESUMEN}

Setenta y cinco caracoles gigantes africanos fueron empleados para investigar el efecto del método y duración del almacenamiento sobre la calidad de sus huevos. Los métodos de almace-

"We thank staff of COLANIM Snail Unit.

\author{
Palabras clave adicionales \\ Archachatina marginata.
}

naje fueron: refrigerador (cold), contenedor en una estantería (ambient) y olla de barro (earthen) durante 1, 2, 3 y 4 semanas. Se midieron características externas (longitud, peso, circunferencia, forma y pérdidas de peso y volumen) e internas (peso y altura del albumen y $\mathrm{pH}$ del huevo). El método de almacenamiento no tuvo efecto sobre las características externas, pero afectó a las internas $(p<0,001)$. La duración del almacenamiento influyó $(p<0,01)$ sobre altura del albumen, y pérdida de peso y volumen. La mayor pérdida de peso del huevo durante las dos primeras semanas de almacenamiento se registró en la olla de barro y aumentó con la duración del almacenamiento. La pérdida de volumen también fue mayor en la olla de barro y menor en el almacenamiento en frío. Se concluye, que el almacenamiento en frío o a temperatura ambiente de los huevos de (Archachatina marginata) durante 1-2 semanas permite mejor calidad.

\section{INTRODUCTION}

The intensive snail production is gradually gaining ground with upsurge of different challenges among which egg handling is a notable one. Recently, egg wastage in commercial snail farms as a result of large egg turnout during the raining season is a major concern among farmers in Nigeria. Most farmers that rear this animal as additional enterprise have no idea of how to 
take good care of their eggs except those laid and buried by the animal are later hatched, otherwise most eggs laid on solid platforms are wasted.

Eggs must be temporarily stored. There is need for adequate storage method which will support production especially during their reproductive season which coincide with the raining season (Akinnusi, 1998). It has been revealed that villagers in both southern and western part of the country gather both the eggs and this animal for delicacy. Presently in Nigeria, demand for snails especially giant African land snails (GALS) outstrips supply (Abiona, 2005).

Egg quality studies are very important to every producer to facilitate production process. Egg storage and quality preservation can be ensured by many methods. This study aims to determine the effects of method and length of storage on snail egg quality in GALS.

\section{MATERIALS AND METHODS}

The experimental site was the Snail Research Unit of the University of Agriculture Abeokuta, Nigeria $\left(7^{\circ} 10^{\prime} \mathrm{N}=\right.$ and $3^{\circ} 2^{\prime}$ $\mathrm{E})$. It is a room of $2.6 \times 3.5 \times 5.6 \mathrm{~m}$ partitioned into 4 compartments. It has in it three tier wooden rack and the fourth, a store room. The materials used include: 75 eggs from land snail, plastic baskets with dimension $24 \times 30 \times 40 \mathrm{~cm}$, plastic bowls with cover, earthen pot, feeding trough, water trough, sun dried top humus soil, sensitive scale, fridge, spherometer, venier caliper, $\mathrm{pH}$ meter, and spatula were used for the experiment. Average temperature and humidity of the snail house were measured with the aid of hygrometer.

Eggs laid were collected, randomly selected and marked. External parameters were taken before being assigned to different storage methods at the rate of 5 eggs per treatment per week. Storage was for 4 weeks. Storage methods used were cold storage (Refrigerator), ambient and earthen pot storage. At the end of storage for 1, 2, 3 or 4 weeks, external parameters of eggs were taken and the eggs broken up to measure the internal quality parameters. External parameters measured include egg weight (EWT), egg length (EGL), egg circumference (EC) and shape index (ESI) while internal parameters measured were albumen weight (AWT), albumen height ( $\mathrm{AH})$ and egg $\mathrm{pH}$.

\section{EVALUATION OFEGG QUALITY}

a. Cold storage: eggs were arranged on egg trays and stored in a refrigerator (Thermocool $\left(\right.$ ) ) at $10^{\circ} \mathrm{C}$ and $86 \%$ relative humidity (1);

b. Earthen pot storage: eggs were placed in an earthen pot (30.24\% sand; $36.96 \%$ clay and $32.80 \%$ silt) and stored at room temperature $\left(32^{\circ} \mathrm{C}\right)$ on a flat surface with a relative humidity of $61 \%$.

c. Ambient temperature storage (control): eggs were placed in egg tray untreated and stored at room temperature $\left(32^{\circ} \mathrm{C}\right)$ and $61 \%$ relative humidity.

Egg quality parameters (external and internal) were measured at 1, 2, 3 and 4 weeks. Eggs were broken out on a flat transparent glass surface using a spatula to obtain various internal parameter measurements. Week one measurements were used as the control for length of storage for each storage method.

The external quality parameters measured were:

I. EGL (in $\mathrm{cm}$ ) using a ruler.

EWT (in grams) using a weighing balance (Scout ${ }^{\mathrm{TM}}$ Pro, Ohaus).

II. EC (in $\mathrm{mm}$ ) using tread and ruler.

The internal quality parameters measured for all the 75 eggs in each storage method on each week of observation were:

I. AH (in cm) using a caliper.

II. $\mathrm{pH}$ with $\mathrm{pH}$ meter.

III. Egg shape index (egg width/egg length*100), according to Panda (1996).

\section{RESULTS AND DISCUSSION}

Table I shows the effect of storage methods on external egg parameters of 
Table I. Effect of storage methods on external egg parameters of GALS. (Efecto de los métodos de almacenamiento sobre los parámetros externos de los huevos de GALS).

\begin{tabular}{lcccc}
\hline & $E G L(\mathrm{~cm})$ & $E G W(\mathrm{~g})$ & $E C(\mathrm{~mm})$ & ESI \\
\hline Ambient & $1.967 \pm 0.031$ & $1.516 \pm 0.021$ & $52.485 \pm 0.469$ & $77.402 \pm 1.384$ \\
Earthen pot & $1.897 \pm 0.032$ & $1.485 \pm 0.021$ & $53.315 \pm 0.478$ & $78.641 \pm 1.411$ \\
Cold storage & $1.933 \pm 0.029$ & $1.528 \pm 0.019$ & $52.832 \pm 0.431$ & $79.144 \pm 1.272$
\end{tabular}

$E G L=$ egg length; $E G W=$ egg weight; $E C=$ egg circumference; $E S I=$ egg shape index.

GALS. Storage methods used had no significant effect $(p>0.05)$ on the external egg parameters mornitored (EGL, EWT, EC and ESI). This is an indication that storage method does not affect the EL, EWT, EC and ESI of the egg which ordinarily are affected in other species. More specifically, if other external parameters are not affected, it is unusual for that of egg weight. Since egg has pore which could facilitate moisture loss, then it is expected that there should be differences in moisture loss considereing the three method of storage.

ACIAR (1998) reported lesser moisture loss for eggs stored in refrigerator compared to other means of storage. Lack of significance in weight may be attributed to shell structure of the snail eggs which may have lesser pore size compared to other specie eggs. In contrast Samli et al. (2005) reported 2.08 and $13.11 \%$ weight reductions respectively, within 5 and 10 days of storage at $29{ }^{\circ} \mathrm{C}$. Similar weight losses were also reported by Akyurek and Okur (2009). Differences in results may also be attributed to the precursor which form the egg shell. Table II, shows the effect of storage methods on internal egg parameters of GALS. Storage methods had high significant effect $(\mathrm{p}<0.001)$ on internal egg parameters (AH, AWT and $\mathrm{pH})$. AWT of the eggs were higher in cold storage and room storage which were not significantly different from each other, followed by earthen pot storage which recorded the lowest value. Considering $\mathrm{AH}$ as well, cold storage had the highest value, followed by room storage while values for earthen pot were also lowest. Albumen quality is a standard measure of egg quality, and it is influenced by genetic (Johnson and Merritt, 1955) and environmental factors such as storage temperature and time (Samli et al., 2005). Changes seen in albumen qualities in this study may be attributed to moisture loss by evaporation through the shell pores and the escape of $\mathrm{CO}_{2}$ from albumen (Robinson, 1987). It was obvious from this study that such losses were more in earthen pot compared to both ambient and cold storage method used.

Silversides et al. (1993) proposed the measuring of $\mathrm{AH}$ to determine egg quality. It is obvious from this study that the higher values recorded for cold storage and room temperature is an indication that both

Table II. Effect of storage methods on internal egg parameters of GALS. (Efecto de los métodos de almacenamiento sobre los parámetros internos de los huevos de GALS).

\begin{tabular}{lccc}
\hline & AWT & AH & PH \\
\hline EP & $0.59 \pm 0.059^{\mathrm{b}}$ & $1.27 \pm 0.082^{\mathrm{c}}$ & $7.87 \pm 0.025^{\mathrm{a}}$ \\
$\mathrm{A}$ & $1.74 \pm 0.058^{\mathrm{a}}$ & $1.99 \pm 0.080^{\mathrm{b}}$ & $7.75 \pm 0.025^{\mathrm{b}}$ \\
$\mathrm{CS}$ & $1.66 \pm 0.053^{\mathrm{a}}$ & $2.39 \pm 0.074^{\mathrm{a}}$ & $7.81 \pm 0.023^{\mathrm{ab}}$ \\
\hline
\end{tabular}

${ }^{a b c}$ Means in the same column with different superscripts differ $(p<0.05)$.

$\mathrm{AWT}=$ albumen weight; $\mathrm{AH}=$ albumen height; $\mathrm{PH}=$ hydrogen ion concentration. $E P=$ earthen pot; $A=$ ambient; $\mathrm{CS}=$ cold storage. 
methods are better compared to earthen pot. The most crucial factor that need to be considered is temperature when it come to storage. Definitely, the reason for higher albumen weight may also be as a result of lower temperature in both cold storage and room storage as compared to earthen pot storage which may have higher temperature becouse of the clay component which attract heat. This observation is in line with the assertion of Samli et al. (2005) that temperature appear to be the most crucial factor affecting albumen quality. Higher values recorded for cold storage, followed by room storage for albumen height is also a comfirmation that these two methods of storage could acertain good membrane integrity of the egg there by maintaining the

\section{REFERENCES}

Abiona, J.A. 2005. Comparative study of the accessory reproductive organs of two species of GALS (Archachatina marginata and Achatina achatina). Dissertation. Department of Animal Breeding and Genetics. University of Agriculture. Abeokuta.

ACIAR. 1998. Measurements and maintenance of duck and hen egg quality in Vietnam. Australian Centre for International Agricultural Research. Research note RN 23 12/99.

Akinnusi, F.A.O. 1998. Introduction to snail and snail farming. Omega Science Publishers. Lagos. Nigeria. pp. 70.

Akyurek, H. and Okur, A.A. 2009. Effect of storage time, temperature and hen age on egg quality in free-range layer hens. J Anim Vet Adv, 8: 19531958.

Johnson, A.S. and Merritt, E.S. 1955. Heritability of albumen height and specific gravity of eggs from white Leghorns and Barred Rocks and the correlations of these traits with eggs production. quality of the egg (Samli et al., 2005). For pH, the opposite was the case. Earthen pot recorded the highest value while cold storage and room storage followed in that order and were not significantly different from each other. The highest values recorded for hydrogen ion concentration $(\mathrm{pH})$ in earthen pot is a clear indication of level of dehydration as orchestrated by higher temperature in the medium. Silversides and Villeneuve (1994) reported that $\mathrm{pH}$ is a useful means for describing changes in albumen quality over time during storage.

It can be concluded, considering quality parameters measured that giant African land snails eggs can be stored with minimal loss for two weeks using both cold and ambient storage methods.

Poultry Sci, 34: 578-587.

Panda, P.C. 1996. Shape and texture. In: Textbook on egg and poultry technology. $1^{\text {st }} \mathrm{ed}$. NewDelhi. India.

Robinson, D.S. 1987. The chemical basis of albumen quality. In: R.G. Wells and C.G. Belyavin (Eds.). Egg quality-current problems and recent advances. Butterworths. London. pp. 179-191.

Samli, H.E.; Agma, A. and Senkoylu, N. 2005. Effect of storage time and temperature on egg quality in old laying hens. J App/ Poultry Res, 14: 548-553.

Silversides, F.G. and Villeneuve, P. 1994. Is the Haugh unit correction for egg weight valid for eggs stored at room temperature? Poultry Sci, 73: $50-55$.

Silversides, F.G.; Twizeyimana, F. and Villeneuve, P. 1993. Research note: A study relating to the validity of the Haugh unit correction for egg weight in fresh eggs. Poultry Sci, 72: 760764. 